УДК: 657.6

JEL Classification: M 42

\author{
О. Ю. РЕДЬКО, \\ сертифікований аудитор, \\ доктор економічних наук, професор, \\ член Аудиторської палати України (1998-2011 рр., \\ 2017-2018 pp.)
}

\title{
Як жити далі вітчизняним аудиторам (новели законодавчого регулювання аудиту в Україні)*
}

Нарешті відбулося те, чого деякі чекали з упевненістю у “світлому майбутньому”, а інші - з такою ж упевненістю в краху своєї професійної діяльності. Ми маємо на увазі прийняття Закону Украӥни "Про аудит фінансової звітності та аудиторську діяльність" від 21.12.2017 p. № 2258-VIII, який набув чинності з 1 січня 2018 p. та вводиться в дію з 1 жовтня 2018 р. На все про все в аудиторській спільноті залишилося 10 місячів на адаптацію до вимог нового законодавчого акту прямої діі. Як $i$ в будь-якому вітчизняному законодавчому акті, в тексті Закону є певні плюси та мінуси для професії, якій вже 25 років.

Ключові слова: закон про аудит, плюси, мінуси, заходи, аудиторська спільнота.

Даючи оцінки (“плюс" або “мінус"), ми виходили з двох позицій. Перша - подобається українським аудиторам або ні, але в найближчі часи вони будуть жити за правилами, максимально наближеними до європейських. Друга - 25-річна практика аудиту в країні виробила певні стереотипи сприйняття професійної діяльності учасниками ринку аудиторських послуг. I ці стереотипи будуть створювати дискомфорт у роботі аудиторів за новим Законом. Основними стереотипами слід вважати: бажання монополізувати ринок аудиторських послуг, бажання встановити регульовані ціни на аудиторські послуги, сприйняття керівниками аудиторських фірм своїх співробітників-аудиторів як власний інтелектуальний капітал, навічно “закріплений” за фірмою, конфлікти інтересів та особисті конфлікти з лідерами аудиторської спільноти ( “два українця - три гетьмана!”). При цьому слід зазначити, що вітчизняні аудитори не звикли підкорятися контролю з боку держави, який і вступає в силу за новим Законом. Але звернемося до самого законодавчого акту.

" Стаття написана станом на 22 січня 2018 р.

(C) О. Ю. Редько, 2018 


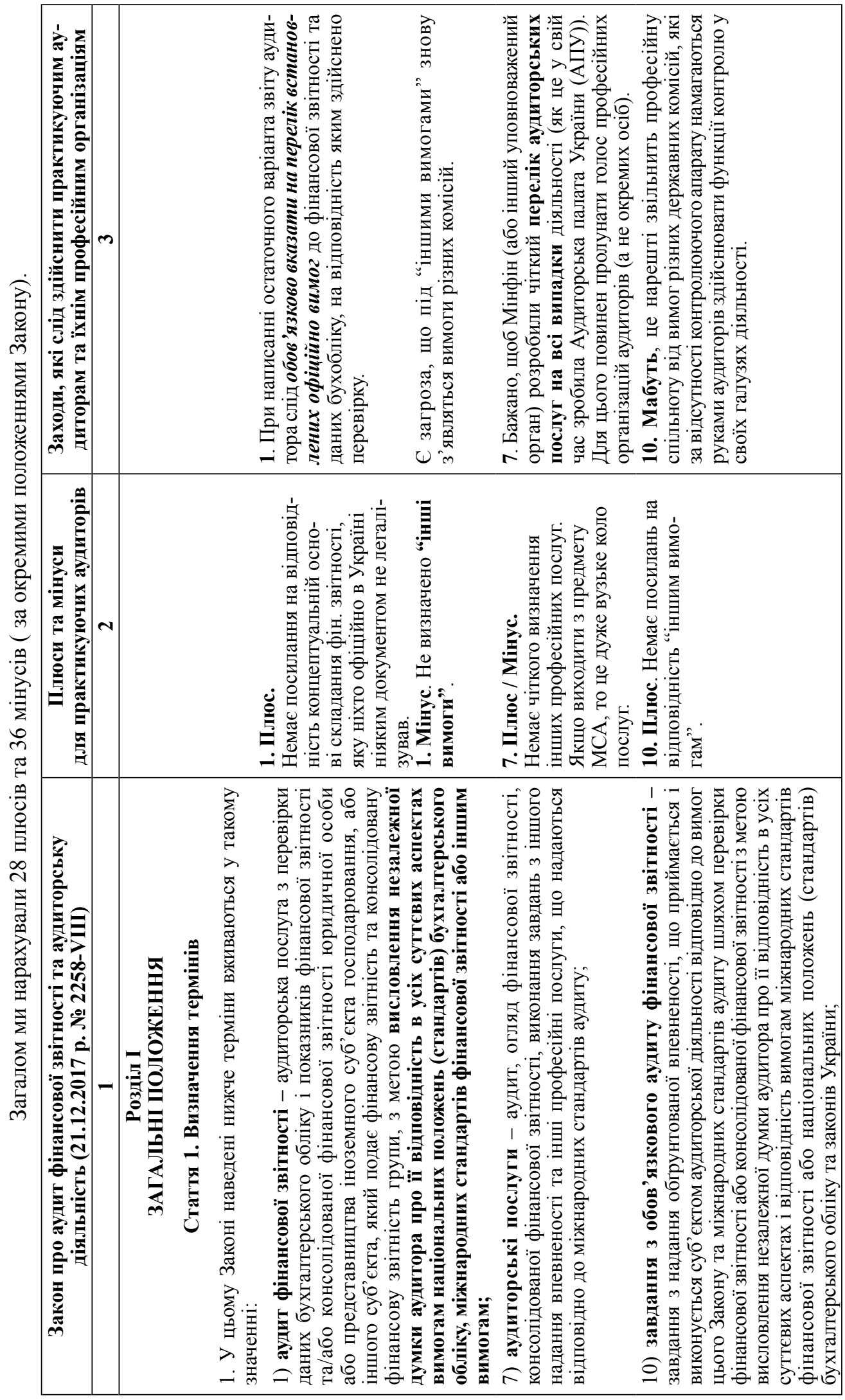




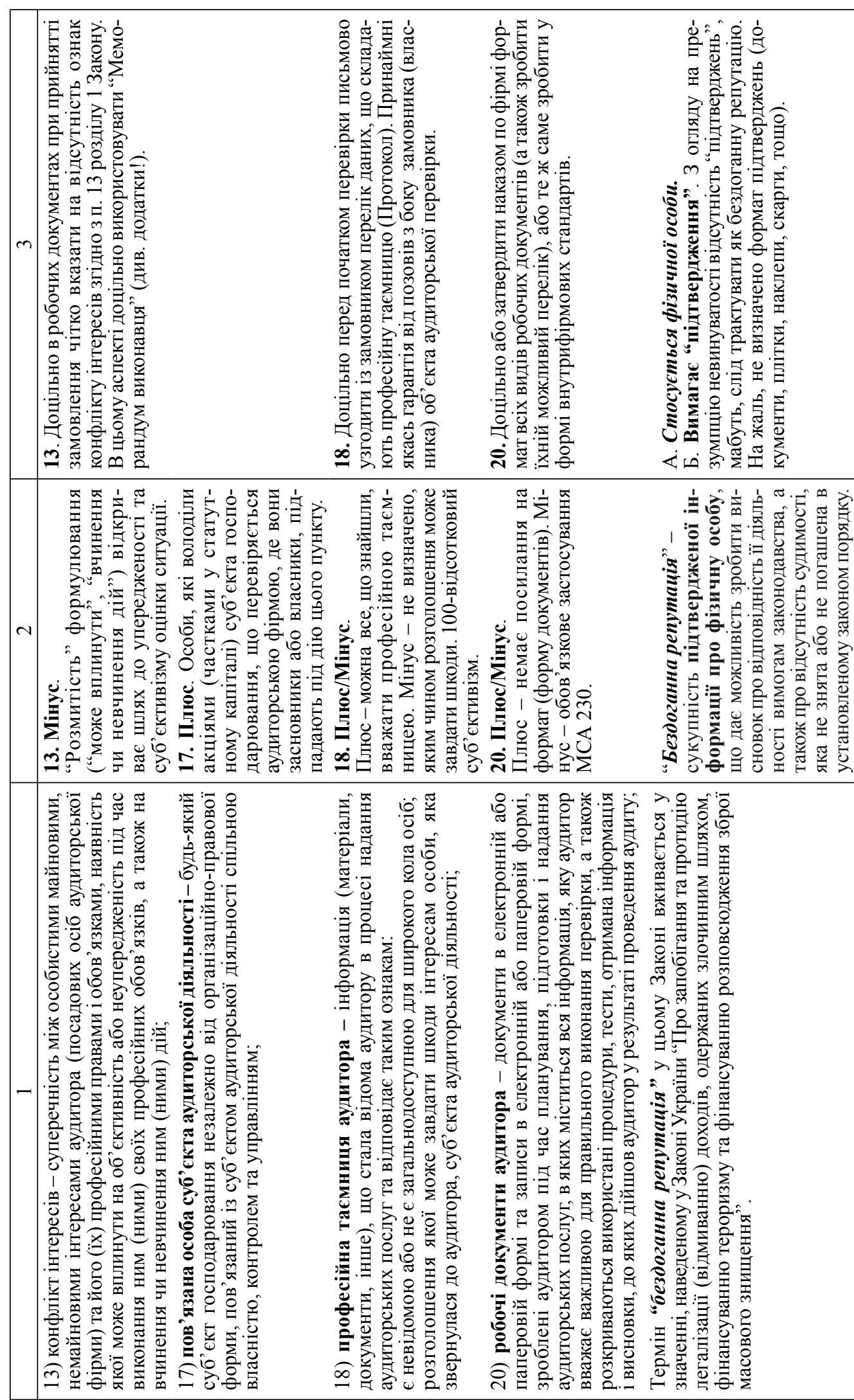




\begin{tabular}{|c|c|c|c|c|c|c|}
\hline$m$ & \multicolumn{3}{|l|}{ 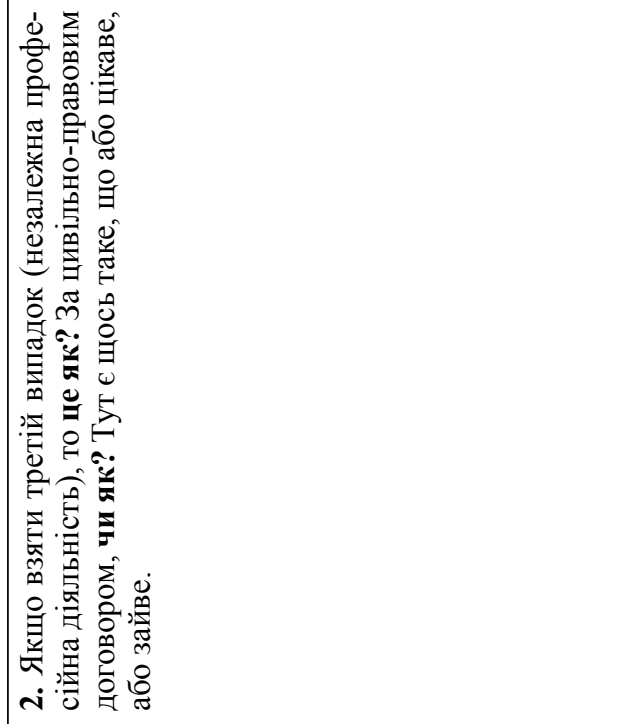 } & \multicolumn{3}{|l|}{ 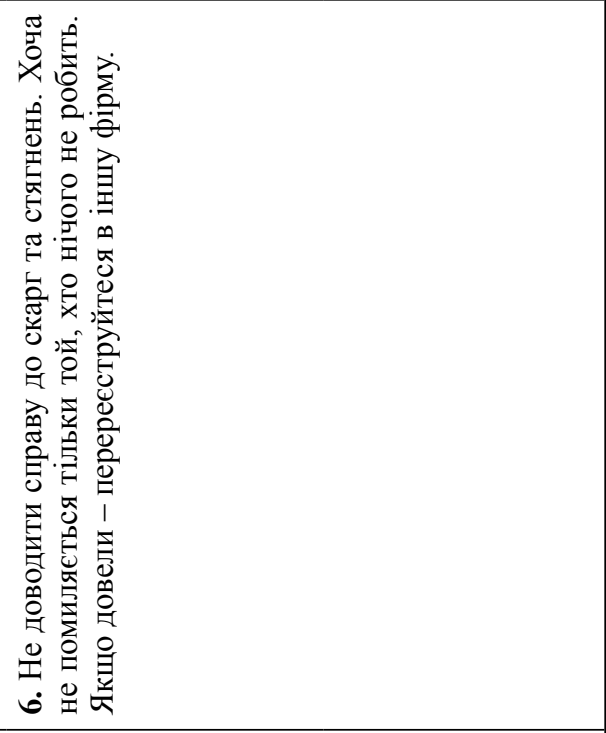 } \\
\hline$\sim$ & 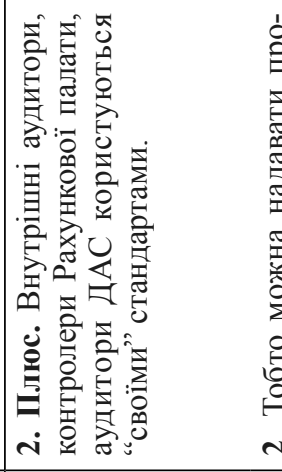 & 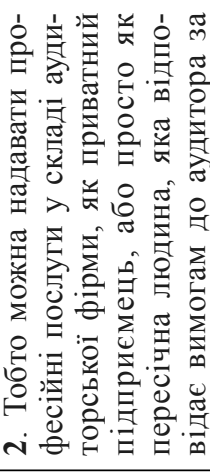 & 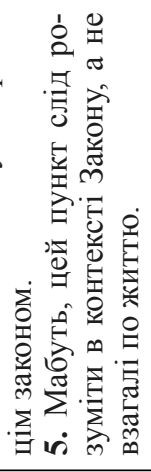 & 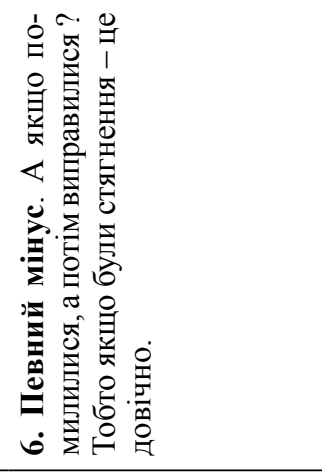 & 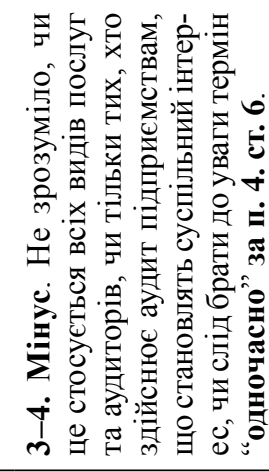 & \\
\hline- & 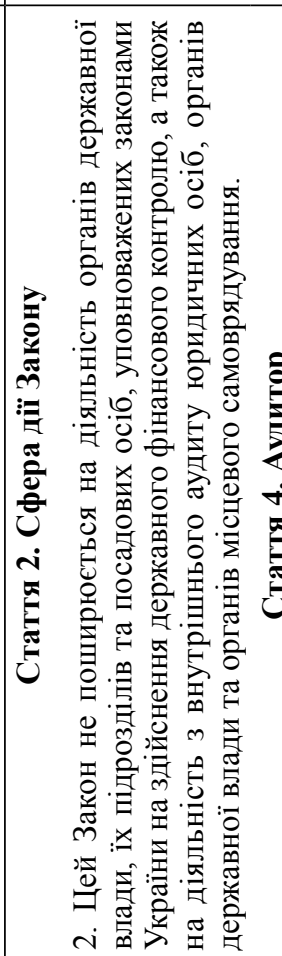 & 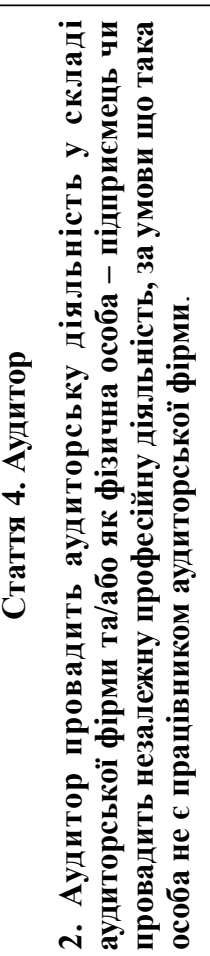 & 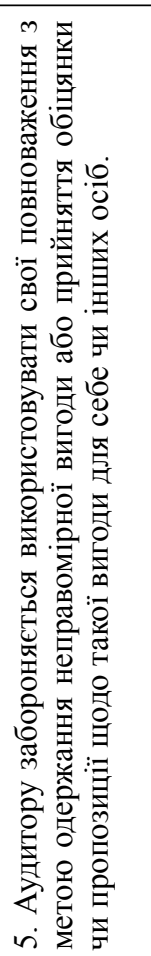 & 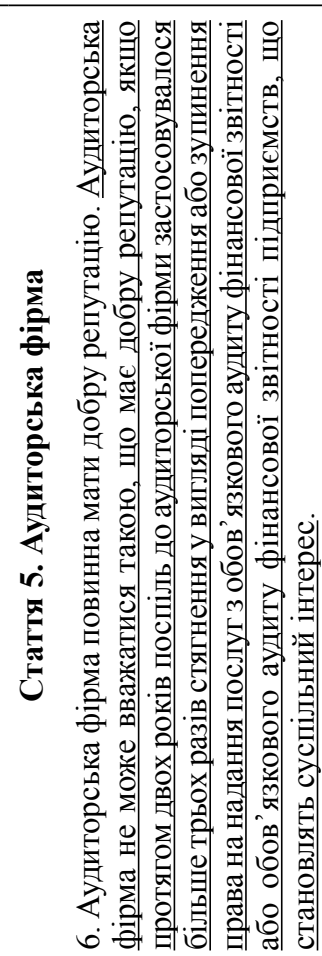 & 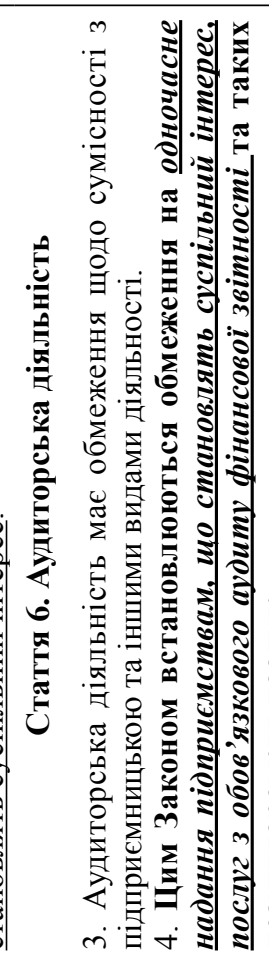 & \\
\hline
\end{tabular}




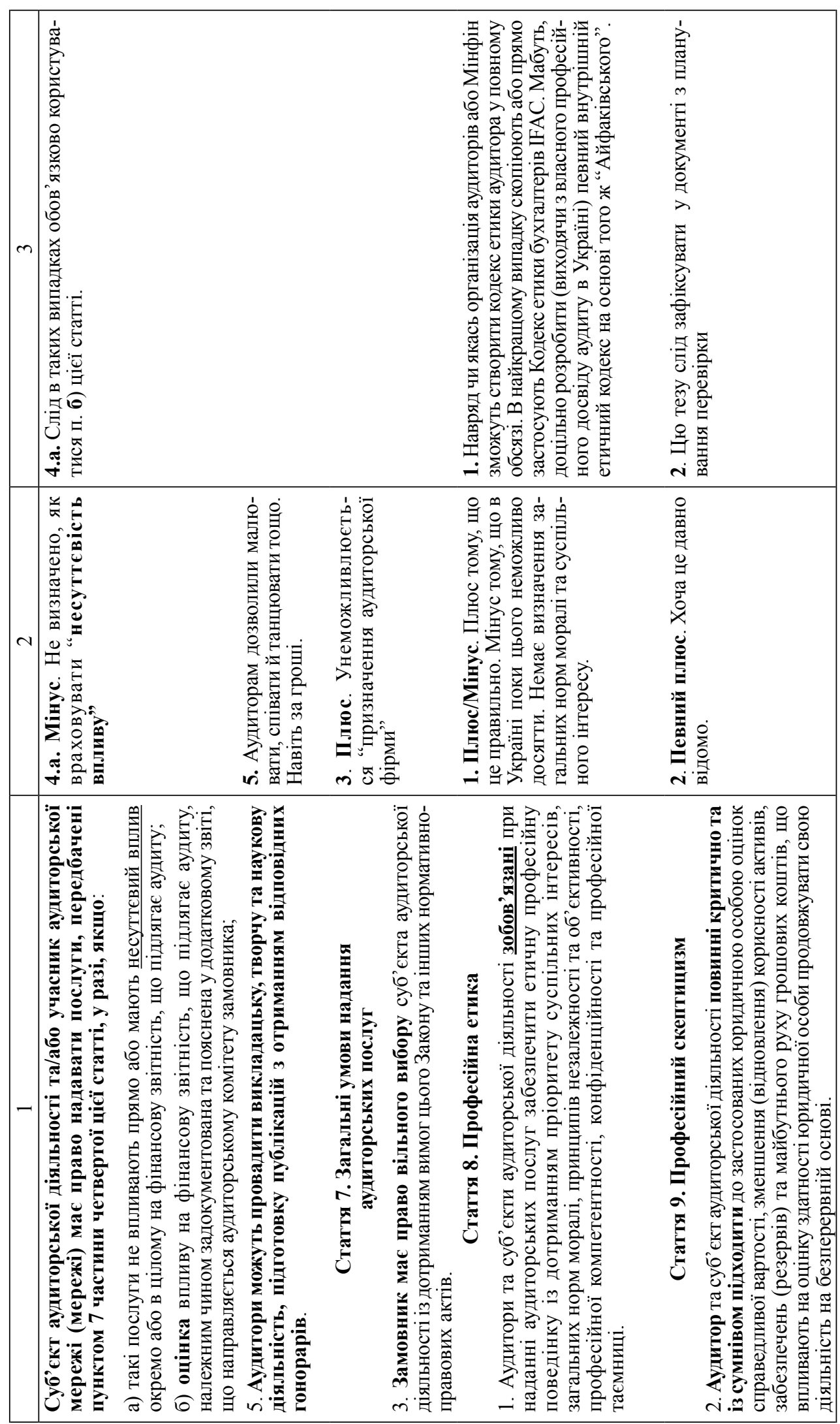




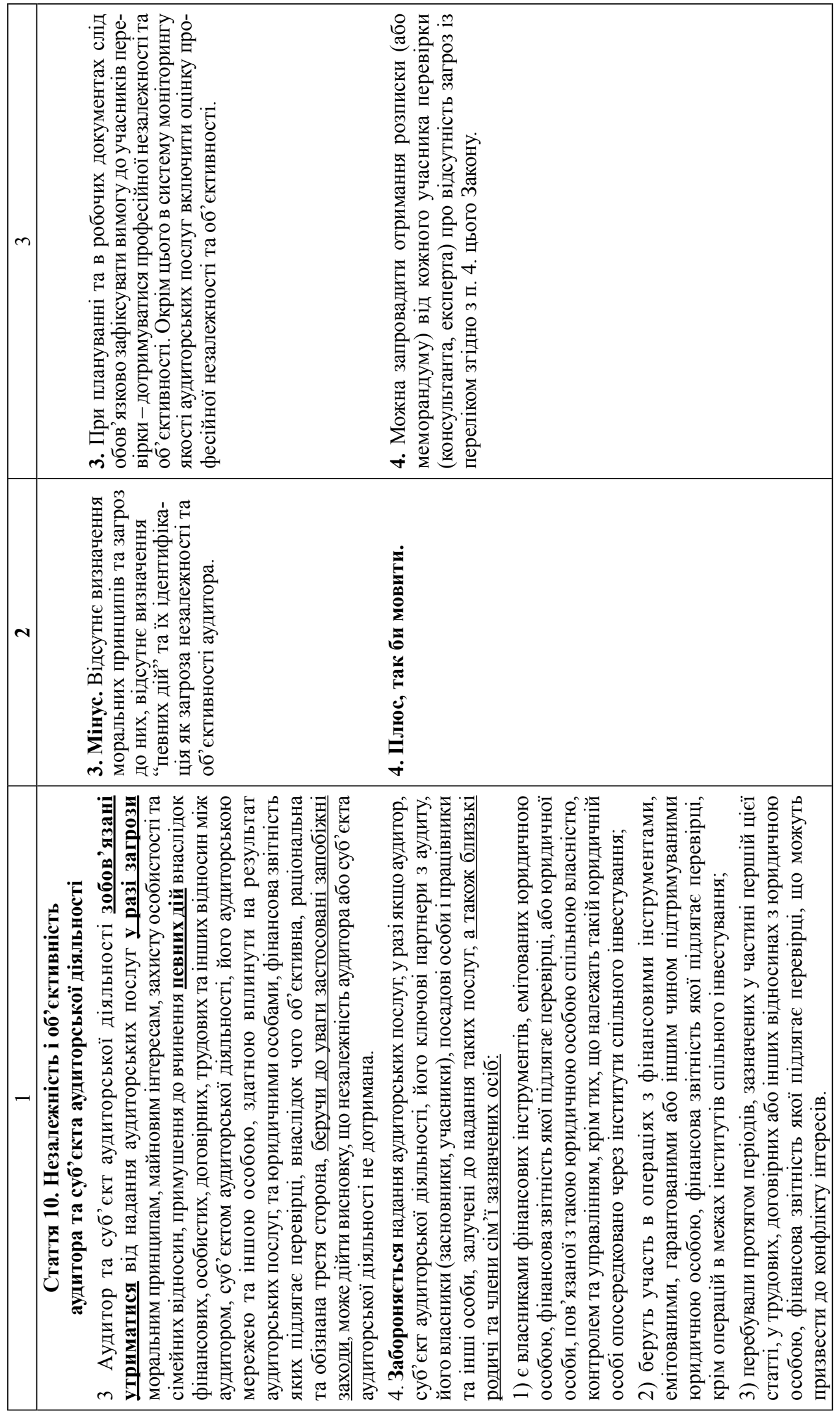




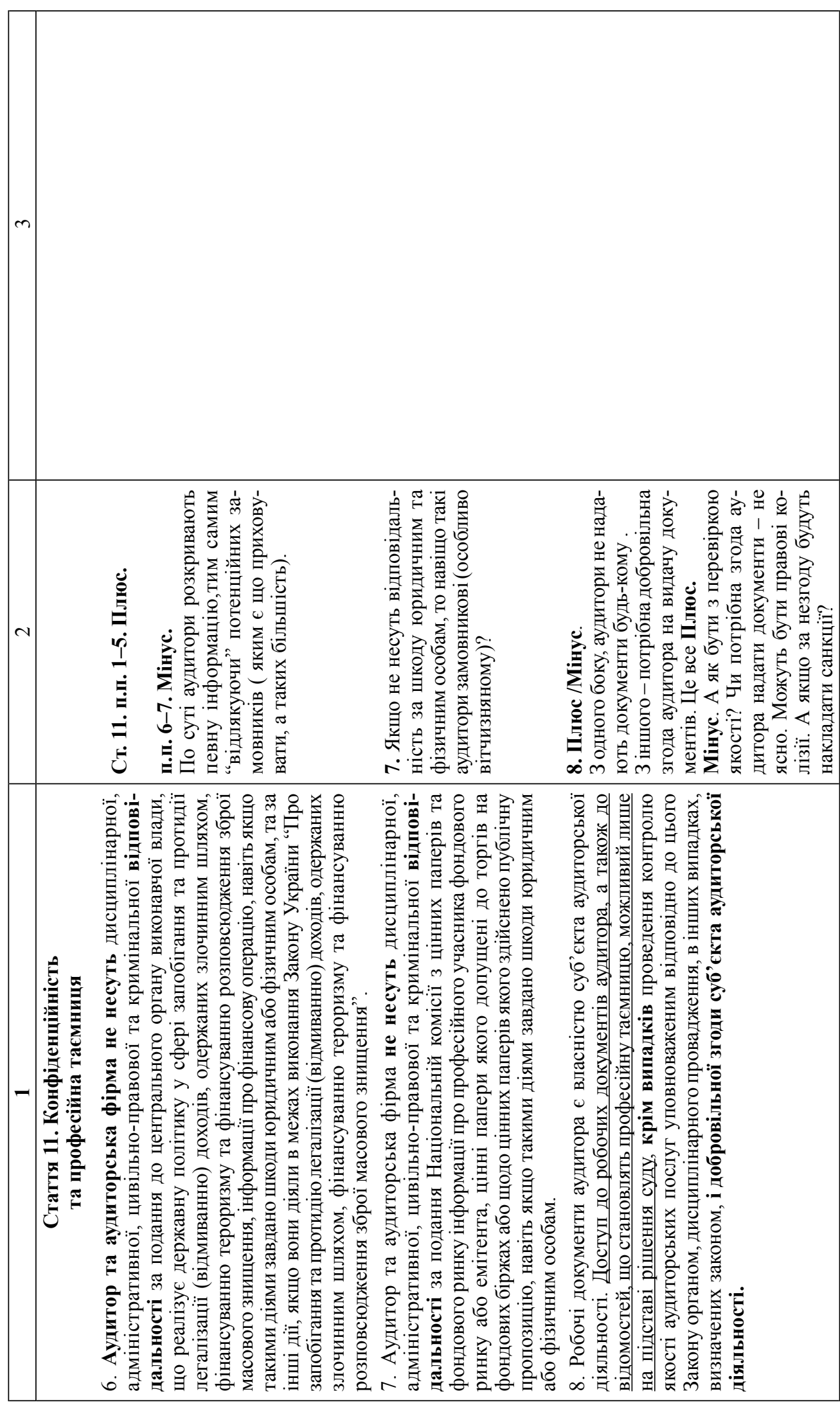




\begin{tabular}{|c|c|c|c|c|c|c|}
\hline$m$ & & & & 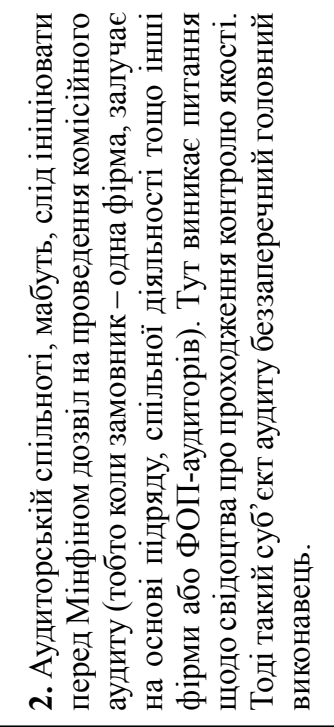 & 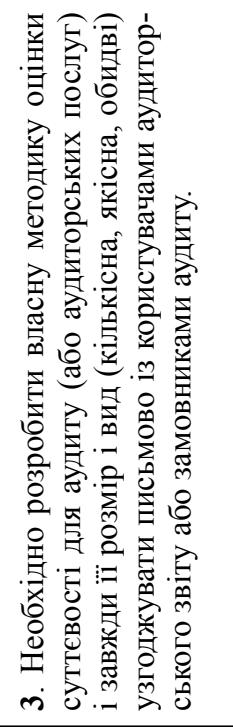 & 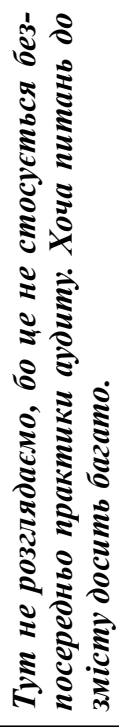 \\
\hline$N$ & & & 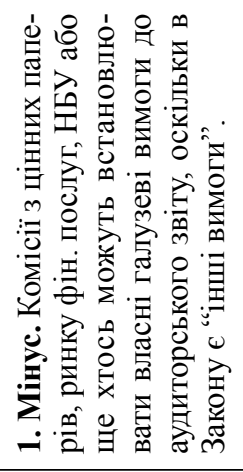 & 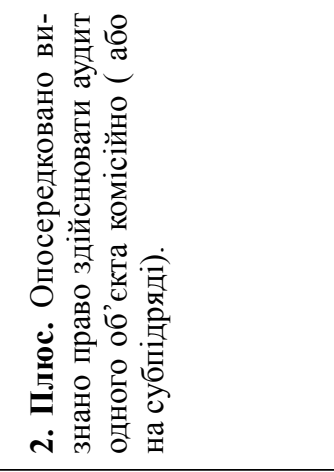 & 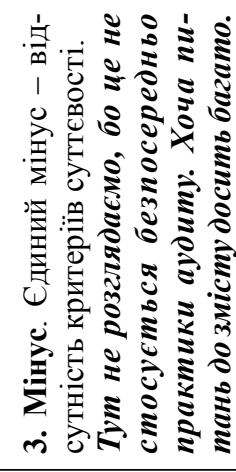 & \\
\hline- & & 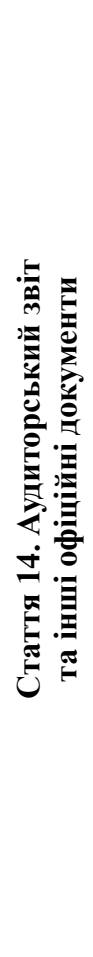 & 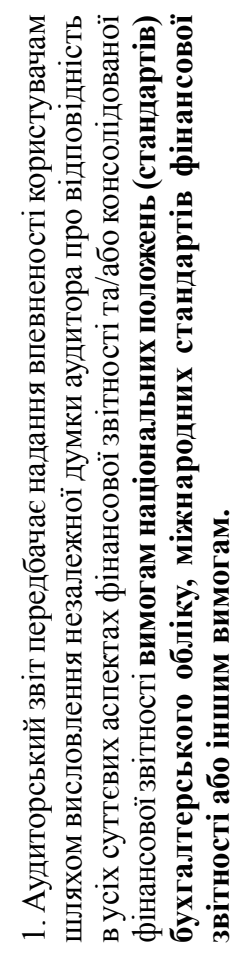 & 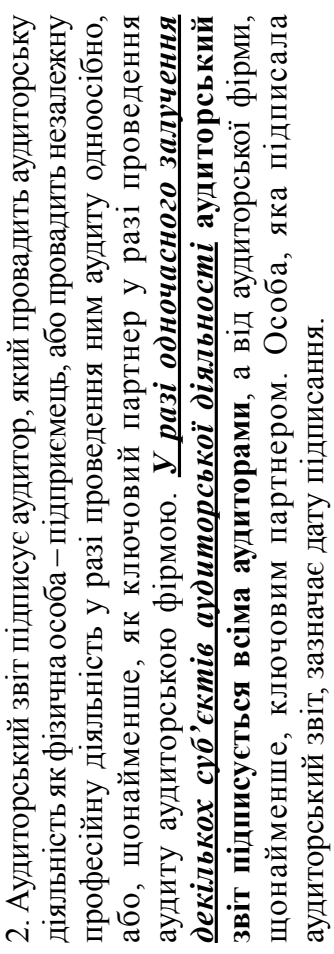 & 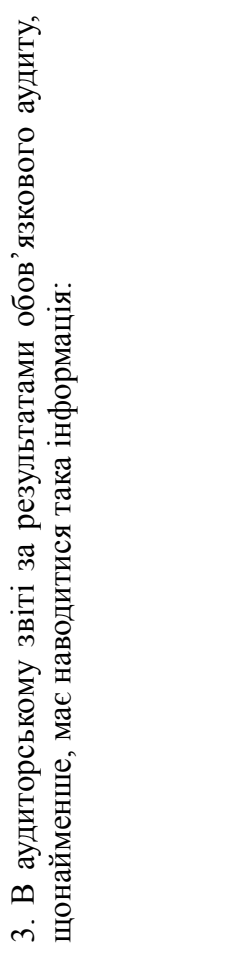 & \\
\hline
\end{tabular}




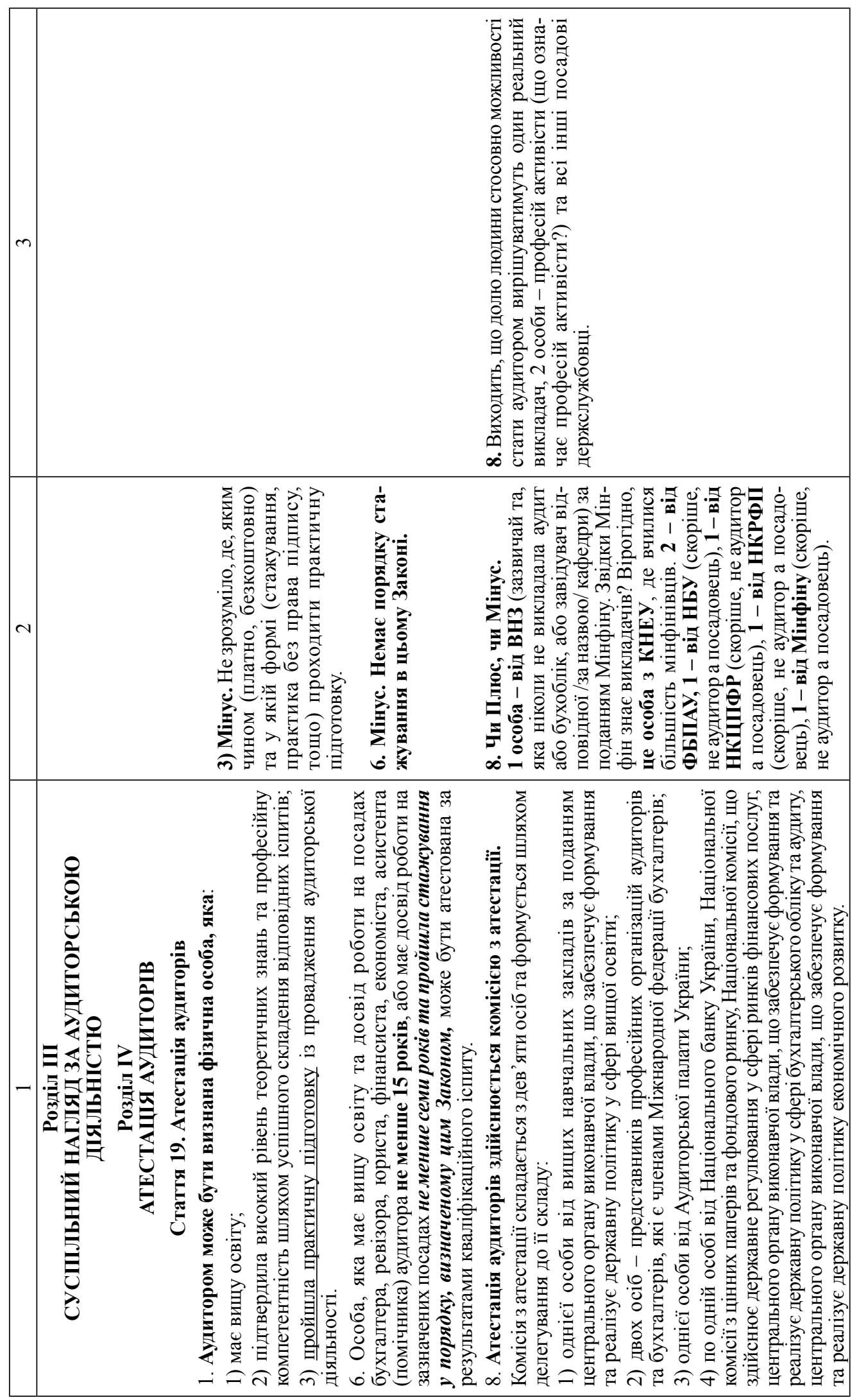




\begin{tabular}{|c|c|c|}
\hline$m$ & & 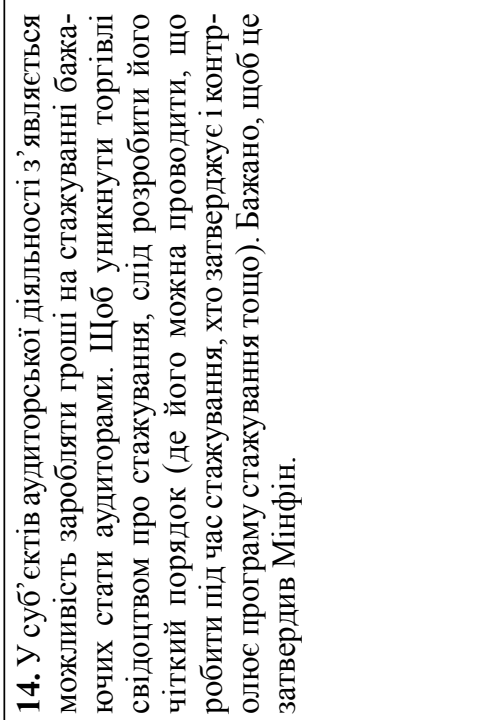 \\
\hline$\sim$ & 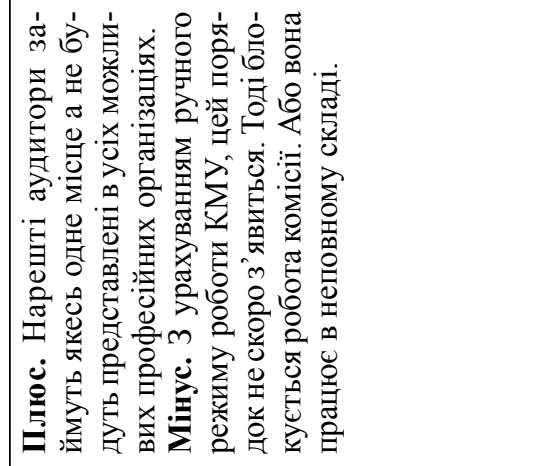 & 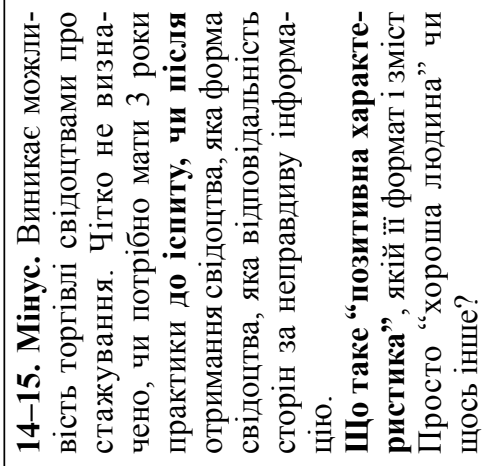 \\
\hline & 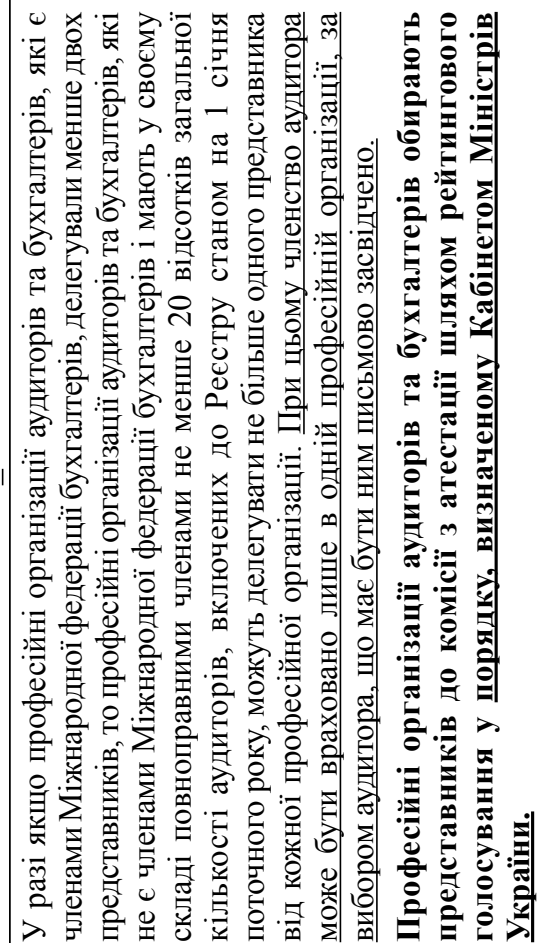 & 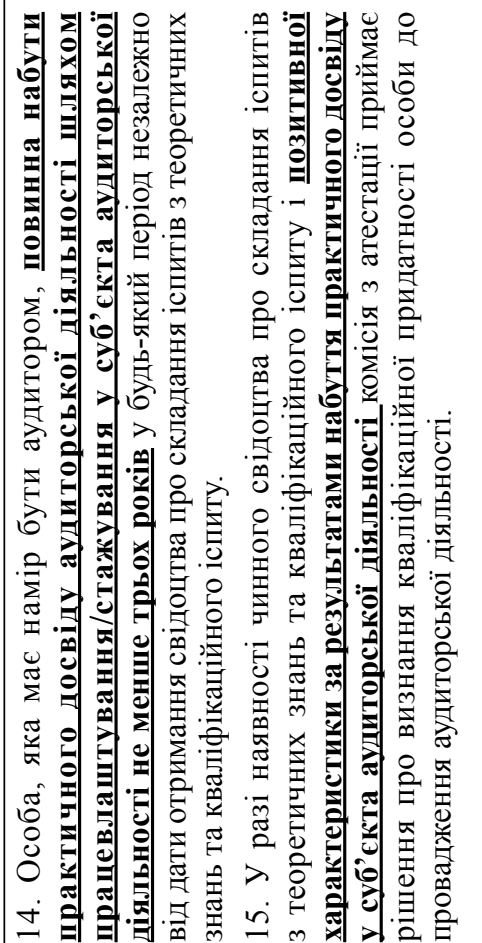 \\
\hline
\end{tabular}




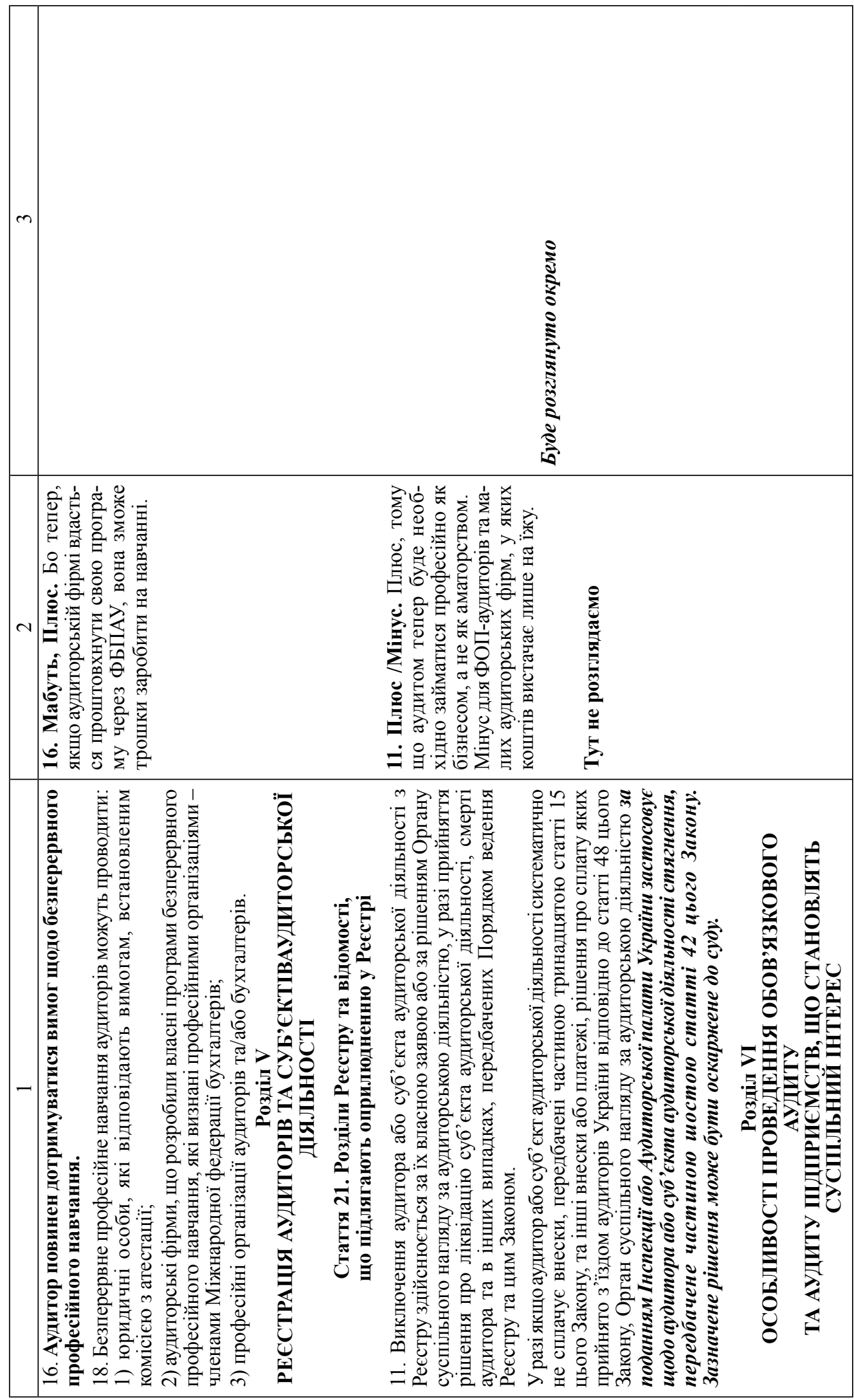




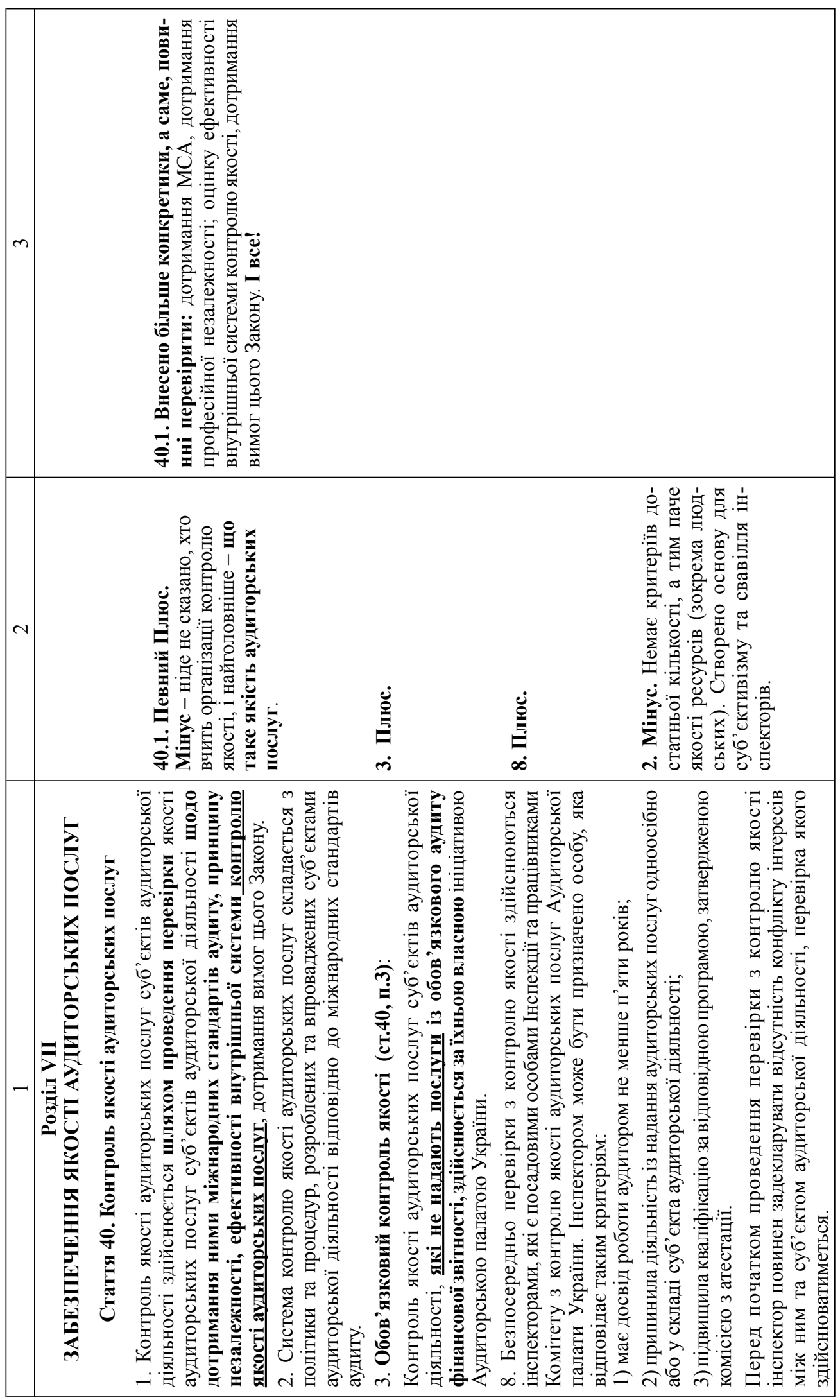




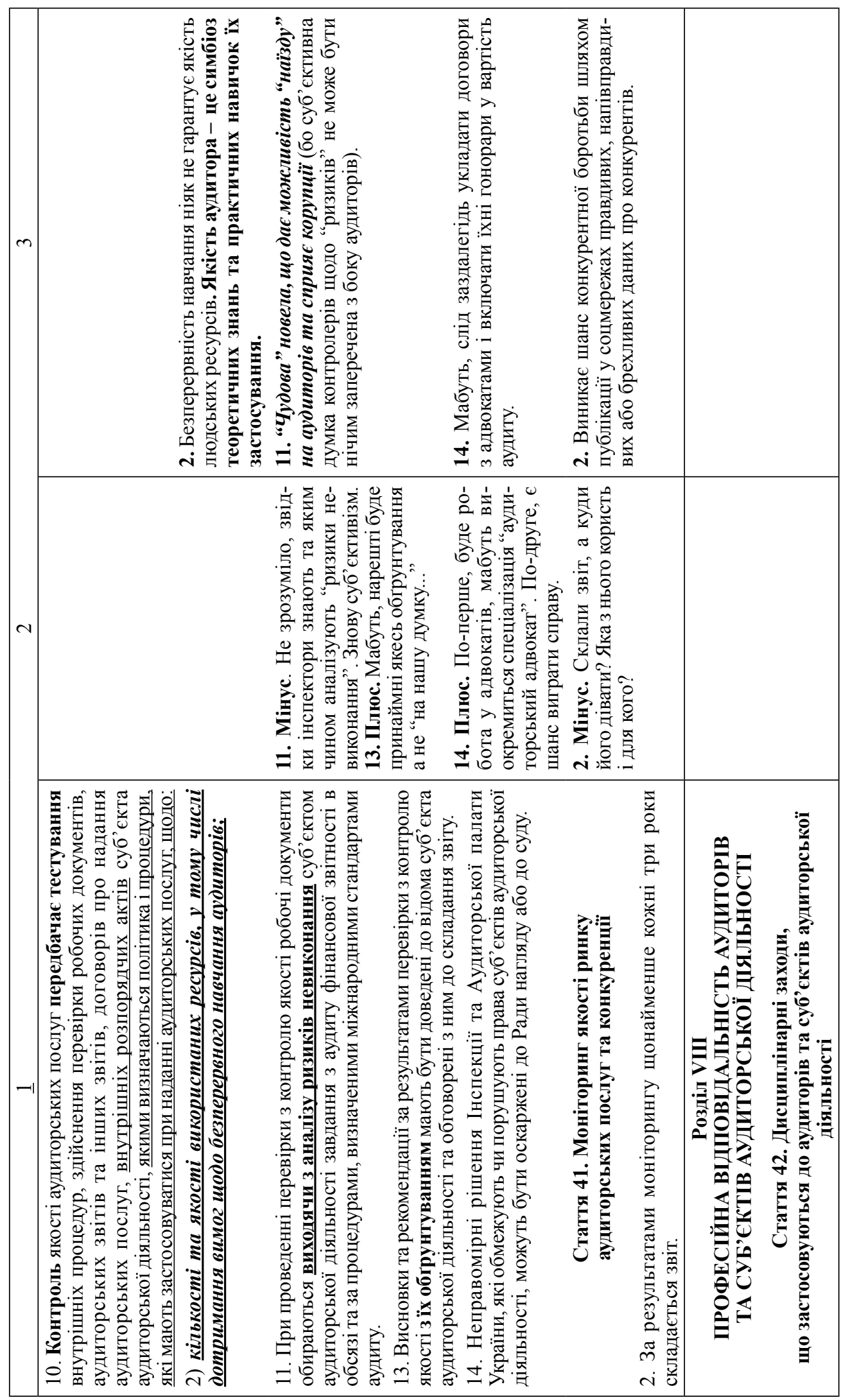




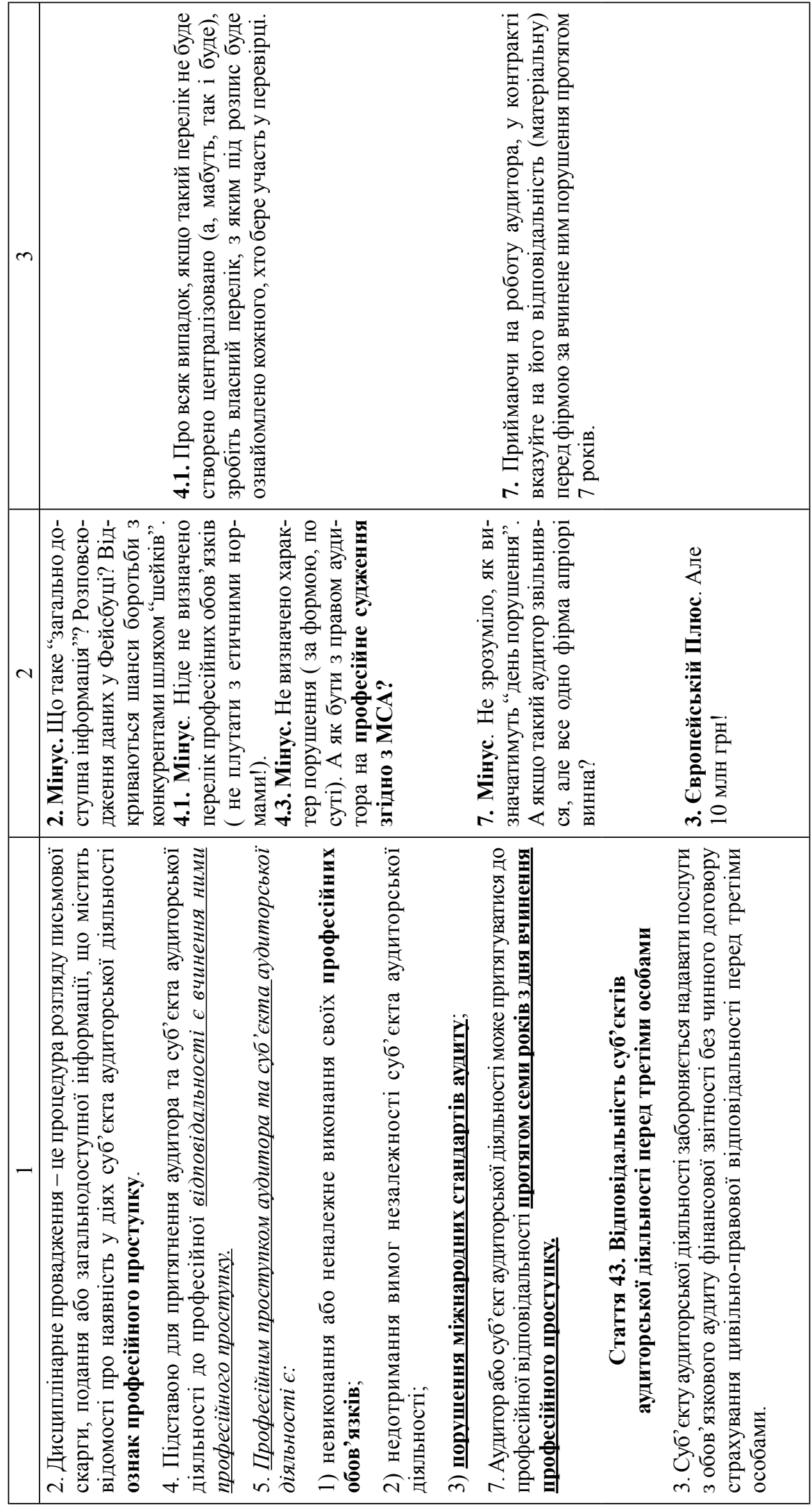




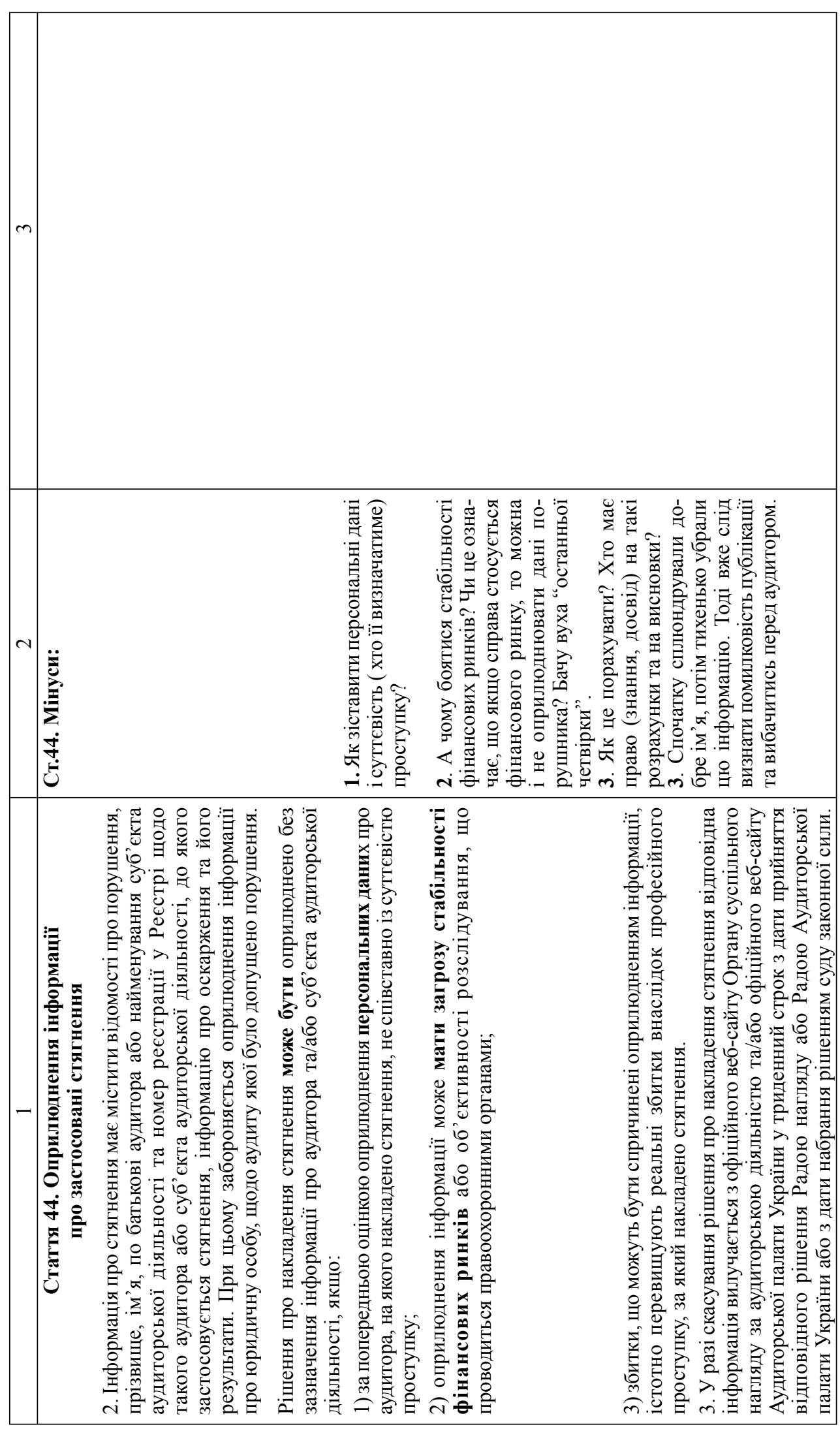




\begin{tabular}{|c|c|c|c|c|c|c|c|c|c|c|}
\hline$n$ & & \multicolumn{9}{|c|}{ 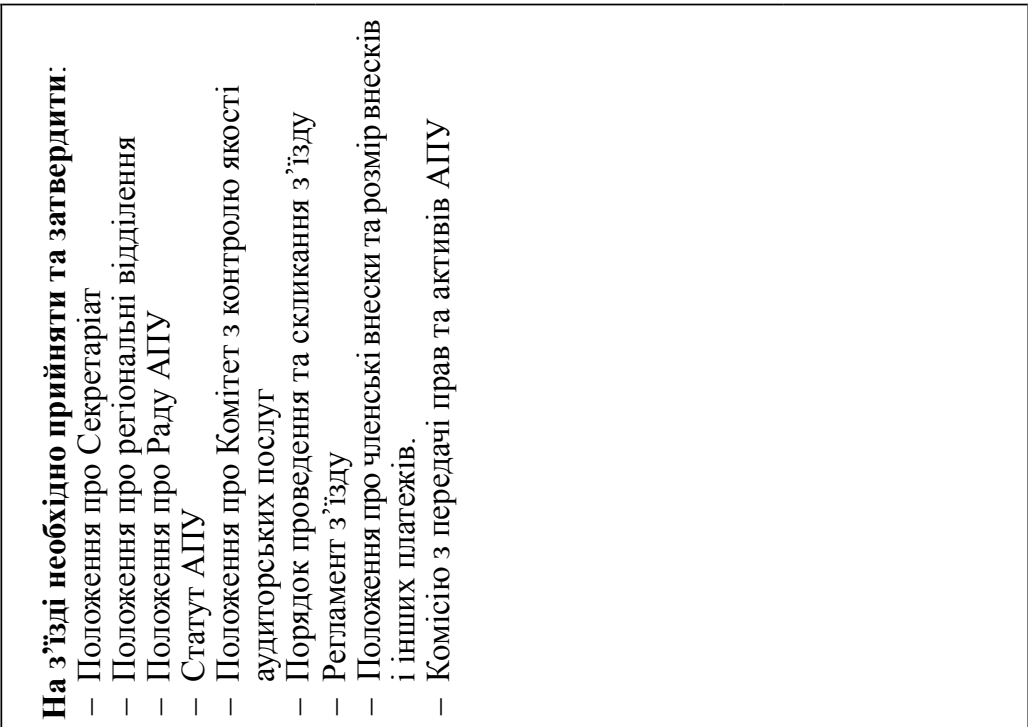 } \\
\hline & 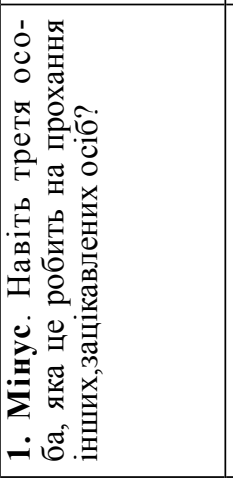 & \multicolumn{7}{|c|}{ 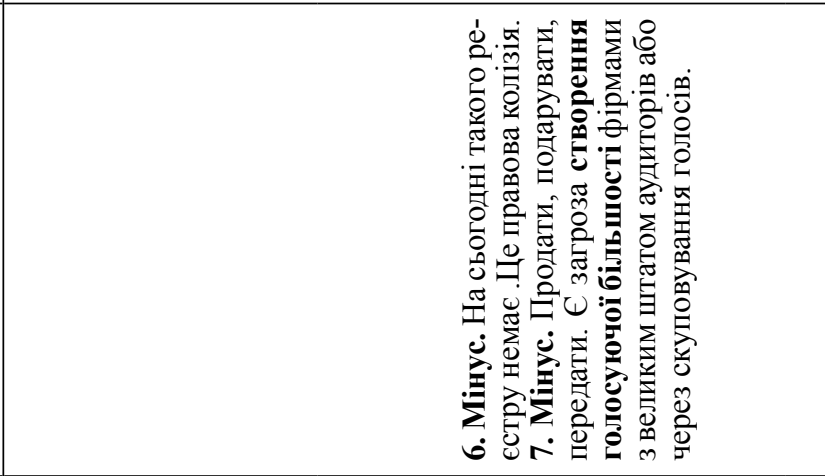 } & \multicolumn{2}{|c|}{ 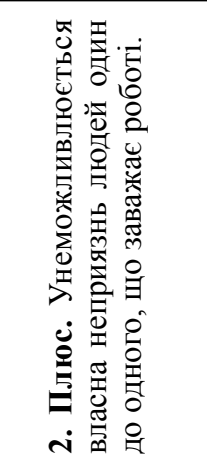 } \\
\hline & 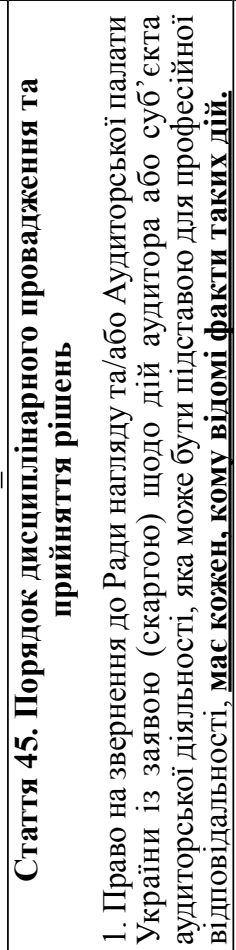 & 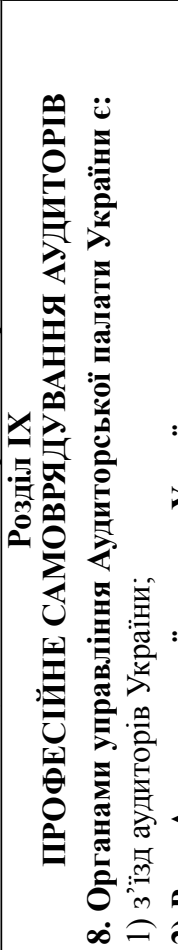 & 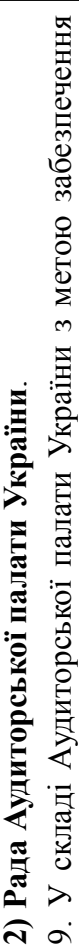 & 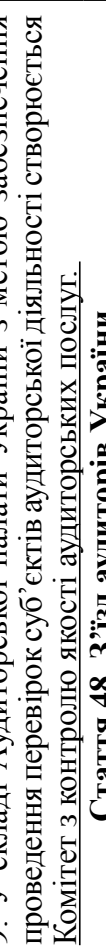 & & & & 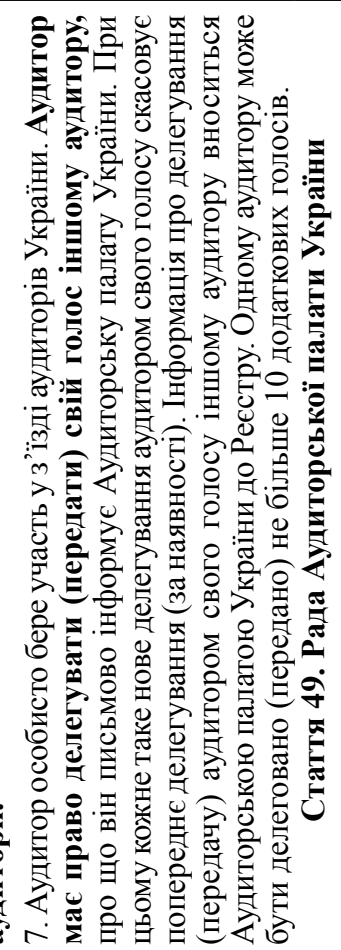 & & 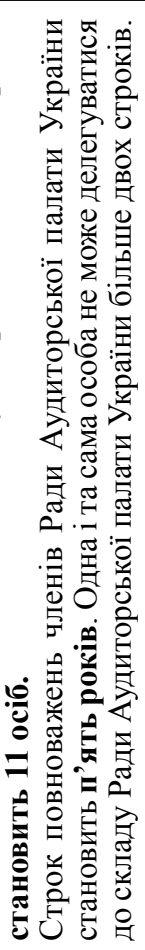 \\
\hline
\end{tabular}




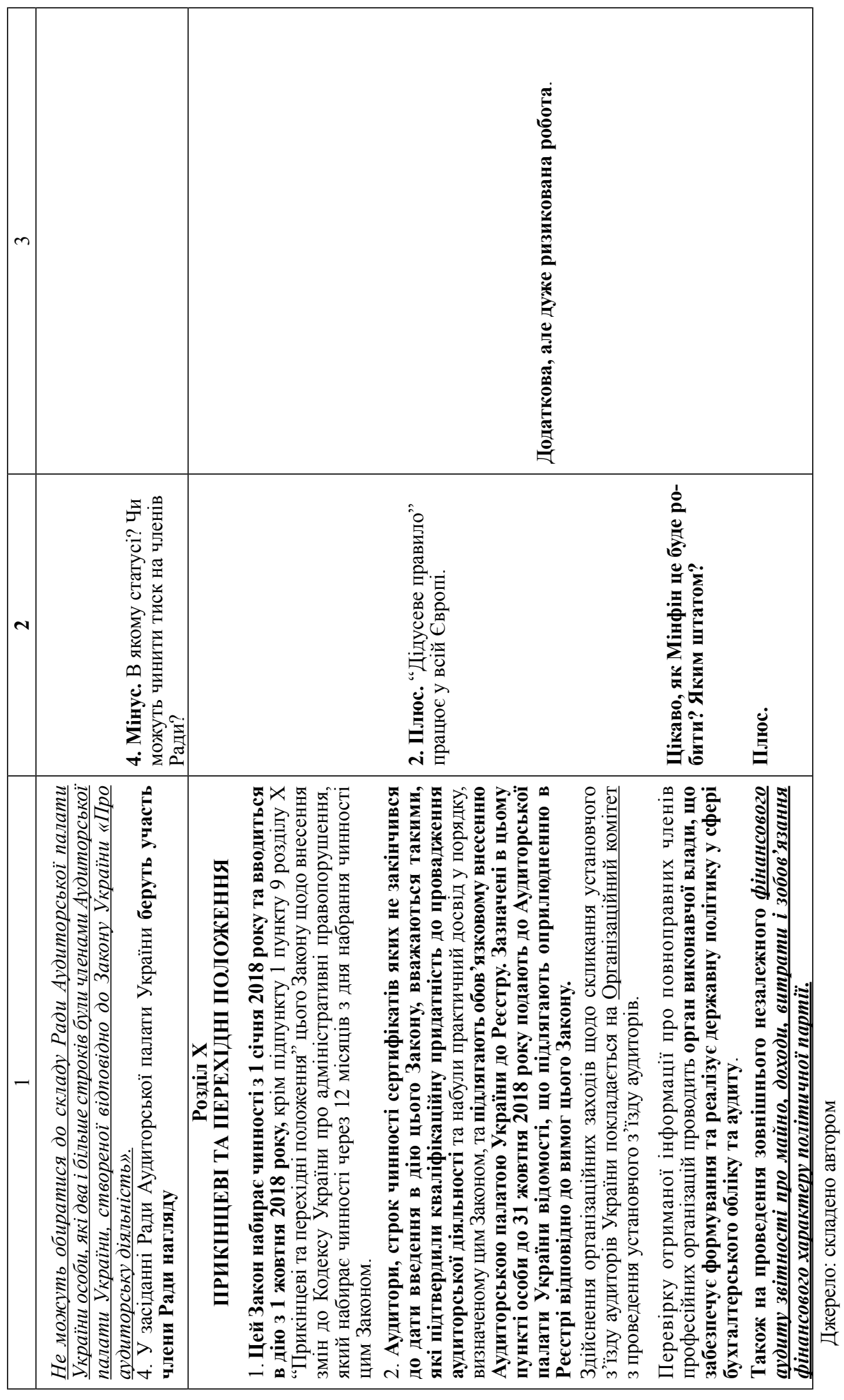


Як бачимо, новий Закон має певні невизначеності, які досить суттєво можуть вплинути на вітчизняну аудиторську практику. Перш за все, це стосується вимог до фінансової звітності та аудиторського висновку. Міжнародні стандарти аудиту (МСА) в усьому світі носять скоріше рекомендаційний, ніж директивний характер. В Україні ж МСА до цього часу розуміли як “істину в останній інстанції”. Великою, на наш погляд, помилкою, $є$ відсутність посилань у Законі на право аудитора мати власне професійне судження. Хоча це право більше 200 разів згадується у тексті МСА, проте його відсутність у Законі залишає можливість для суб'єктивного підходу до аудиторської практики при контролі якості аудиторських послуг.

Щодо контролю якості. Відсутність визначення якості аудиту цілком зрозуміла. Якість послуг може визначити тільки їх отримувач (користувач результатів аудиту). Визначати якість аудиту - все одно що визначати “якість” лікаря або судді. На жаль, Закон, який вперше в історії українського аудиту на такому високому рівні встановив вимогу до контролю якості, має безліч “розмитих" вимог та тез. Так, у п. 10 ст. 40 існують такі об'єкти перевірки як “кількість та якість використаних ресурсів, у тому числі вимог щодо безперервного навчання аудиторів”. Виникає закономірне питання, яким чином можливо виміряти “якість” практикуючого аудитора? На нашу думку, $є$ якісний потенціал, який складається з теоретичних знань та практичних навичок їх застосування (професійний досвід). Але як визначити якість його, потенціалу, практичне застосування в тій чи в іншій ситуації? Відомо, що само по собі “безперервне навчання" розширює світогляд $i$, знову ж таки, поглиблює теоретичні знання. А як бути з практикою? На такі прості питання Закон відповіді не дає та, мабуть, і не повинен давати. $Є$ надія на конкретні підзаконні акти, проте, беручи до уваги потенціал лідерів вітчизняної аудиторської спільноти та їхні інтереси, $є$ небезпека скочування до елементарної боротьби з конкурентами за рахунок “розмитості” термінів, їх двозначного трактування та суб'єктивних упереджених оцінок. Не менш цікавим $\epsilon$ положення (абз. 3 п. 10 ст. 40) про перевірку (в ході контролю якості) “дотримання вимог стосовно винагороди за аудиторські послуги”. Щоправда, є доповнення - “якщо вони встановлені”.

Вартість аудиту - це взагалі найболючіша тема для української професійної спільноти. Не існує методик визначення вартості аудиторських послуг, і тому вона буде завжди визначатися як “справедлива”, що одночасно влаштовує як аудитора, так і замовника.

Ознайомлення з новим Законом навіть у першому наближенні дозволяє зробити такі основні узагальнені висновки:

- Аудиторська практика буде більш забюрократизованою. На кожне замовлення аудиторська фірма повинна буде складати більше різноманітних документів у діапазоні від “Меморандуму аудитора" до “Переліку вимог, за якими складено звітність".

- Стан ринку аудиту залежатиме від встановлення диференціації суб'єктів аудиту на дві рівновеликі групи: професійні аудиторські фірми та всі інші. При цьому в останній ми спостерігатимемо безперервну ротацію учасників ринку.

- Якість аудиторських послуг залишатиметься незмінною до того часу, поки підзаконними актами не буде встановлено чіткі їі (якості) критерії та правила перевірки.

- Новітня професійна організація аудиторів - Аудиторська палата України повинна сформуватися не лише за рахунок “нових облич”, а й поміркованих практиків саме українського аудиту (а не з “останньої четвірки” чи вітчизняних політиканів або державних службовців).

3 огляду на певний досвід роботи в керівних органах аудиту в Україні маленька надія на позитивні зрушення все ж таки є. Але сумніви поки що переважають. 


\section{сертифицированный аудитор, доктор экономических наук, профессор, член Аудиторской палаты Украины (1998-2011 г2., \\ Как жить далыше отечественным аудиторам (новеллы законодательного регулирования аудита в Украине)}

А. Ю. РЕДЬКО, 2017-2018 22.)

Наконец произошло то, чего одни ждали с уверенностью в «светлом будущем», а другие - с такой же уверенностью в крахе своей профессиональной деятельности. Мы имеем в виду принятие Закона Украины «Об аудите финансовой отчетности и аудиторской деятельности» от 21.12.2017 2. № 2258-VIII, который вступил в силу с 1 января 2019 г. и вводится в действие с 1 октября 2018 г. Аудиторскому сообществу осталось всего-навсего 10 месяцев на адаптацию к требованиям нового законодательного акта прямого действия. Как и в любом отечественном законодательном акте, в тексте Закона имеются определенные плюсы и минусы для профессии, которой уже 25 лет.

Ключевые слова: закон об аудите, плюсы, минусы, меры, аудиторское сообщество.

O. Yu. REDKO,

Certified Auditor,

Dsc (Economics), Professor,

Member of the Auditor Chamber of Ukraine (1998-2011,

2017-2018)

\section{How Should Domestic Auditors Live on (Novels of Legislative Regulation of Audit in Ukraine)}

The article is written in form of the author's review of the Law of Ukraine "Audit of Financial Reporting and Auditing" from 21.12.2017, adopted on January 1, 2018, which will be enforced on October 1, 2018. Like any other domestic legal act, this Law has its strong and weak sides (signified in the text as "plus" and "minus") for the occupation that is 25 years old in Ukraine.

Assessments of strong and weak sides of the new Law are made with two considerations born in mind. The first one that Ukrainian auditors will have to live very soon by the rules adapted as maximally as possible to European ones; the second one is that 25 years of audit practice in Ukraine have formed certain professional image and stereotypes of audit services, which will supposedly create a discomfort in the auditors' work by the new Law. The main stereotypes are intentions to monopolize the market of auditor services and fix its prices; treatment of audit personnel by managers of audit firms as ones whose intellect and competencies are "appropriated" by a firm; conflicts of interests and personal conflicts with leaders of the audit community. It should be remembered that domestic auditors have not been prone to obey the administrative control to be enforced by the new Law. The review of the Law results in 28 weak sides and 36 strong sides revealed and explicated in table form. It allows for making the following general conclusions: the auditor practice will be more bureaucratized than before; the market performance will depend on the breaking of audit entities into the two equal groups: professional audit firms and the rest, with the expected perpetual rotation in the latter group; the quality of audit services will not change unless quality criteria and rules of audit are clearly defined in the subsidiary legislation; a new professional organization of auditors, the Auditor Chamber of Ukraine, need to be staffed with rational practitioners from the Ukrainian audit rather than politicians or public officers.

Keywords: Law on Audit, "plus", "minus", measures, audit community.

Посилання на статтю:

Редько О. Ю. Як жити далі вітчизняним аудиторам (новели законодавчого регулювання аудиту в Україні) // Науковий вісник Національної академії статистики, обліку та аудиту: зб. наук. пр. 2018. № 1-2. С. 77-95. 